\title{
Sedimentary organic matter and acid volatile sulfide as environmental quality indicators of Kagoshima Bay
}

\author{
Nguyen Dung Thi Phuong*, Hiroto Maeda**, Yosuke Taoka*, Masayasu Hidaka***, \\ Takeshi Yoshikawa**** and Taizo Sakata****
}

\begin{abstract}
To estimate the mechanism of dynamic in sediment quality relative to eutrophication, we compared several parameters and characterized the sediments in Kagoshima Bay. This study analyzed sedimentary organic matter and acid volatile sulfide (AVS) as possible indicators of eutrophication. The sediment samples were collected in the months of July, 2001 and August, 2002. Organic matter and AVS concentrations of the sediments showed heterogeneous horizontal distribution and did not appreciably change over a period of one year. The ignition loss (IL) concentrations ranged from $1.1 \%$ to $13.4 \%$, while total organic carbon (TOC) and total organic nitrogen (TON) ranged from $0.2 \%$ to $2.3 \%$ and $0.04 \%$ to $0.22 \%$, respectively. Higher values for IL, TOC and TON were observed in various stations of the inner area and in deep basin stations of the central area of the bay. The parallel increase in TOC and TON with IL suggested that the distribution profiles of TOC and TON in the sediments should be closely associated with IL. Concentrations of AVS ranged from $0.01 \mathrm{mg} /$ $\mathrm{g}$ to $2.2 \mathrm{mg} / \mathrm{g}$ of sediment (dry weight) with high values observed in the deep basin of the inner area. Vertical distribution analysis showed decreasing concentrations of IL, TOC and TON with increasing sediment depths in the inner parts of the bay. On the other hand, no marked differences among sediment depths in concentrations of these parameters were observed in the central area. These results give the clear picture of the horizontal and vertical characterization of sediment in Kagoshima Bay. These also indicated that organic matter and AVS concentrations could be used as indicators for assessing environmental quality of Kagoshima Bay.
\end{abstract}

Key words : acid volatile sulfide, environmental quality, Kagoshima Bay, organic matter, TOC, TON

\section{Introduction}

Sediments provide the substrate for organisms and

Received : January 4, 2005 ; Accepted : December 24, 2005

* The United Graduate School of Agricultural Sciences, Kagoshima University 1-21-24, Korimoto, Kagoshima 890-0065, Japan

** Department of Life Sciences, Faculty of Bioresources, Mie University 1515 Kamihama, Tsu 514-8507, Japan

*** Department of Environmental and Information Sciences, Faculty of Fisheries, Kagoshima University 4-20-50, Shimoarata, Kagoshima 890-0056 Japan

**** Department of Biochemistry and Technology of Aquatic Resources, Faculty of Fisheries, Kagoshima University 420-50, Shimoarata, Kagoshima 890-0056 Japan through interaction with the overlaying waters (e.g., nutrient cycling) ; play an essential role in the aquatic ecosystem. They are essential and integral part of water systems representing the record of all processes of the water column and the autochthonous and allochthonous organic matter inputs that accumulate at the bottom (Fabiano and Danovaro, 1994). Hence, the concentration of sedimentary organic matter is an important indicator that can be used in the assessment of marine environmental quality (Fabiano, 1995). Most studies addressing the assessment of environmental quality of coastal water are based on the $\mathrm{N}$ and $\mathrm{P}$ concentrations (Vollenweider et al., 1998), since these substances are closely associated with the levels of sedimentary organic matter concentration. 
Coastal eutrophication is a recognized phenomenon (Nixon, 1995) that may result in serious ecological changes such as oxygen reduction and hypoxia. Under anoxic conditions, sulfate-reducing bacteria use the oxygen bound in sulfate ions as electron acceptor thereby reducing the sulfate ion to sulfide (Heijs et al., 1999). A poisonous gas, hydrogen sulfide that readily dissolves in water is thus formed. No higher life forms can survive in condition containing hydrogen sulfide, and such areas are eventually transformed into oceanic deserts. Environments containing hydrogen sulfide have a negative redox potential and therefore are reducing media that affect availability of other substances essential to life (Postgate, 1984). The appearance of hydrogen sulfide in an environment is a good indicator of eutrophication and their concentrations in the sediments are able to serve as an important index in evaluating marine environmental quality.

Kagoshima Bay is an important resource for both capture and culture-based fisheries in Japan. However, economic development since the 1960s, adversely affected the water quality of the bay manifested by red tide blooms that started appearing in 1977 (Kazuyuki, 1991). The seriousness of the problem was highlighted by the huge damage to fisheries especially aquaculture, caused by the red tide of Heterosigma akashiwo that occurred in 1995. Despite the legal control of wastewater and aquaculture discharges in preventing pollution, eutrophication still exists as indicated by the recurrence of red tide blooms and the depletion of dissolved oxygen in the bay. The dissolved oxygen concentrations continued to decrease from 1995 to 2000 particularly in the hypolimnion layers of the inner parts of the bay where eutrophic conditions were also observed (Maeda, 2001).

The aim of this study is to identify indicators to assess environmental quality of Kagoshima Bay on the basis of organic matter and acid volatile sulfide concentrations in the sediments. To achieve this, an extensive study of the inner and the central parts of the bay was conducted.

\section{Materials and methods}

\section{Study area and sampling procedures}

Kagoshima Bay occupies the central part of $\mathrm{Ka}$ goshima Prefecture, located between $30^{\circ} 59^{\prime} \mathrm{N}$ to $32^{\circ} 11^{\prime} \mathrm{N}$ latitude and $130^{\circ} 06^{\prime} \mathrm{E}$ to $131^{\circ} 12^{\prime} \mathrm{E}$ longitude. Kagoshima Bay has length of about $75 \mathrm{~km}$ from north to south and a width of about $25 \mathrm{~km}$. The bay is divided into three areas, the inner, central and bay mouth. The Sakurajima volcano is located between the inner and central areas of the bay. The channel between Sakurajima and Kagoshima City is narrow $(1.9 \mathrm{~km})$, with a depth of about $40 \mathrm{~m}$. Its mouth is also narrow $(8.7 \mathrm{~km})$ with a depth of about $80 \mathrm{~m}$ (Fig. 1). The bottom topology of Kagoshima Bay presents a shape similar to two conical bowls connected together (Fig. 2). Due to this condition, replacement of seawater in the bay is very slow, especially in the inner area. The central area is the widest among the three and presents a basin-like topography with the maximum depth of about $230 \mathrm{~m}$. The western half of the inner area has flat bottom topography with a depth of about $140 \mathrm{~m}$ while in the northeastern part, there is a depression of about $200 \mathrm{~m}$ deep. The boundary between the eastern and western parts of the inner area presents a ladder-like topography deepening eastward from the west.

Sediment samples were collected from 48 stations in July 2001 and 35 stations in August 2002 in both the inner and central areas. These months represented periods of low dissolved oxygen concentrations in the bay during the whole year. Although there were more stations designated in the central area, the bottom topography of the bay makes collection of sediments difficult, which resulted in no samples were collected in some stations.

Sediment samples collected by K.K. core (Kimata et al., 1960 a) sampler were placed in plastic boxes and stored at $4^{\circ} \mathrm{C}$ while on board and in $-20^{\circ} \mathrm{C}$ in the laboratory until analysis. Sediment samples for acid volatile sulfide analysis were treated with zinc acetate immediately after collection.

\section{Water and sediment analyses}

Dissolved oxygen (DO) contents at $5 \mathrm{~m}$ above sediments were measured in July 2001. DO contents were estimated by the standard Winkler technique (Grasshoff et al., 1999).

All analyses of sediment samples collected in July 2001 were carried out for the top $1 \mathrm{~cm}$ layer. Analyses of August 2002 samples were carried out for $0-1 \mathrm{~cm}, 2-3$ $\mathrm{cm}, 6^{-7} \mathrm{~cm}$ and $9-10 \mathrm{~cm}$ layers of sediments. Sediment porosity was determined according to the equation : (wc/ $1.02) /([(1-w c) / 2.64]+w c / 1.02)$ where wc is (wet-dry sediment weight)/wet weight (Danovaro et al., 1999a). Sediment samples $(\mathrm{n}=2)$ treated with $2 \mathrm{ml}$ of $1 \mathrm{~N} \mathrm{HCl}$ (to remove inorganic carbon interference) were analyzed for total organic carbon (TOC) and total organic nitrogen (TON) using a Perkin-Elmer 2400 Series II CHNS/O. Ignition loss (IL) was calculated by getting the difference between dry weights $\left(100^{\circ} \mathrm{C}, 24\right.$ hours $)$ of the sediment, and weight of the residue after combustion at $450^{\circ} \mathrm{C}(2$ hours) expressed in percent. Total acid volatile sulfide 
(AVS) was separated by steam distillation under acidic condition and trapped in 10\% zinc acetate solution. Trapped sulfides were determined by spectrophotometric methylene blue method (Truper and Schelegel, 1964).

\section{Statistical analysis}

Pearson correlation was performed to test relationships among environmental parameters, moisture, IL, TOC, TON and AVS. Likewise, their levels at different sediment depths in both the inner and central areas were analyzed using ANOVA. The different between the inner and central area of the bay were analyzed using T-test.

\section{Results}

\section{Dissolved oxygen (DO) contents}

DO in the water column taken at $5 \mathrm{~m}$ above sediments in July 2001 was very much lower in the inner area than in the central area (Fig. 3). Hypoxia condition occurred in northeast area of the inner area, where the concentrations of DO at many stations were less than $3 \mathrm{mg} / 1$. In the inner area, even in the upper layer of water column, dissolved oxygen of as low as $4 \mathrm{mg} / 1$ was observed. In the central area, DO concentrations in most of stations were

$130^{*} 29^{*} E$

$130^{\circ} 51^{\circ} \mathrm{E}$

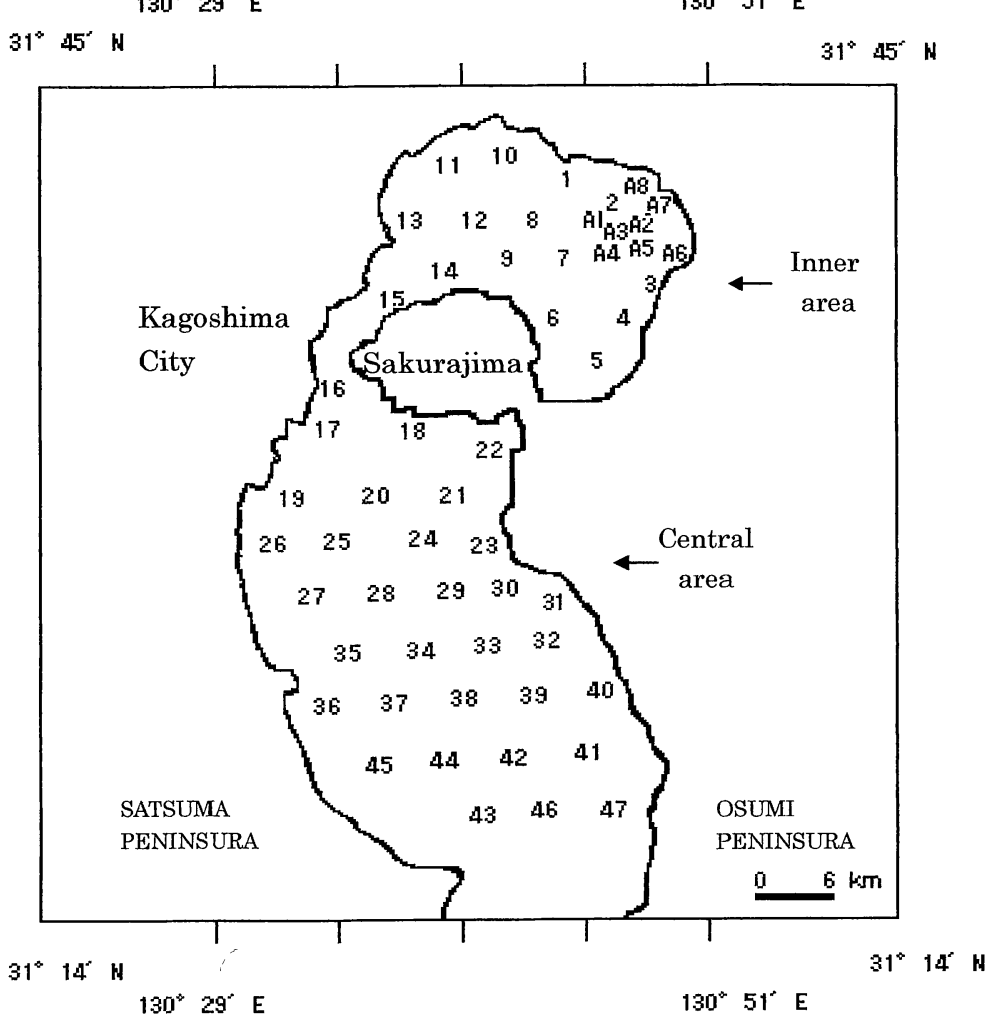

Fig. 1 Index map of sampling stations.

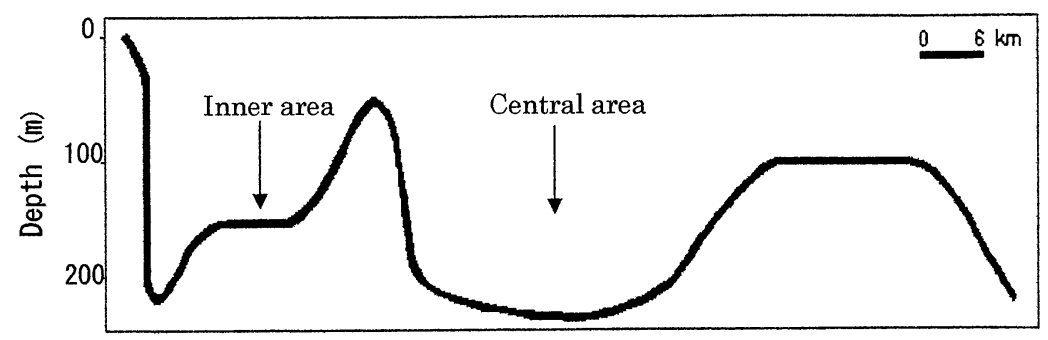

Fig. 2 Vertical section of Kagoshima Bay. 

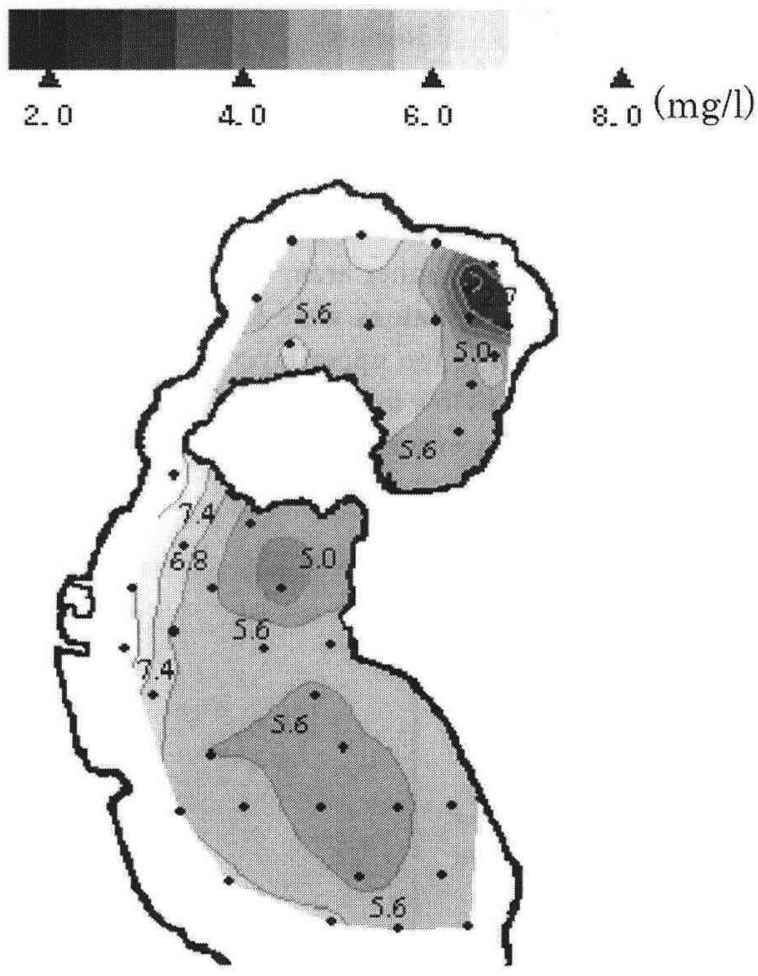

Fig. 3 Dissolved oxygen (DO; $\mathrm{mg} / \mathrm{l}$ ) at $5 \mathrm{~m}$ above bottom sediment collected in July 2001.

more than $6 \mathrm{mg} / \mathrm{l}$. DO concentrations about 4.7 to 5.5 $\mathrm{mg} / 1$ were found in the deep part area in the central area.

\section{Sediment water content and porosity}

There were significant differences in water content and porosity between the inner and the central areas of the bay. However, the deeper stations at 29, 33 and 41 of the central area, had similar levels with most stations of the inner area. There is a similar trend in the depth profile of water content and porosity at the stations both in the inner and central areas ; they decreased significantly with increasing sediment depths (Tables 1 and 2). Data collected in August 2002 showed that the highest levels were at the $0-1 \mathrm{~cm}$ top sediment layer.

3. Ignition loss, total organic carbon and total organic nitrogen of sediments

Ignition loss (IL) in the sediment of Kagoshima Bay was comparatively very high and showed heterogeneous horizontal distribution without appreciably changes over a period of one year (Fig. $4 \mathrm{a}$ and Fig. $4 \mathrm{~b}$ ). The highest values of $\mathrm{IL}$ were observed at the stations of the inner area, while the lowest values were at the stations along the coast of Mt. Sakurajima in the central area. Vertical distribution of IL showed different trend between the
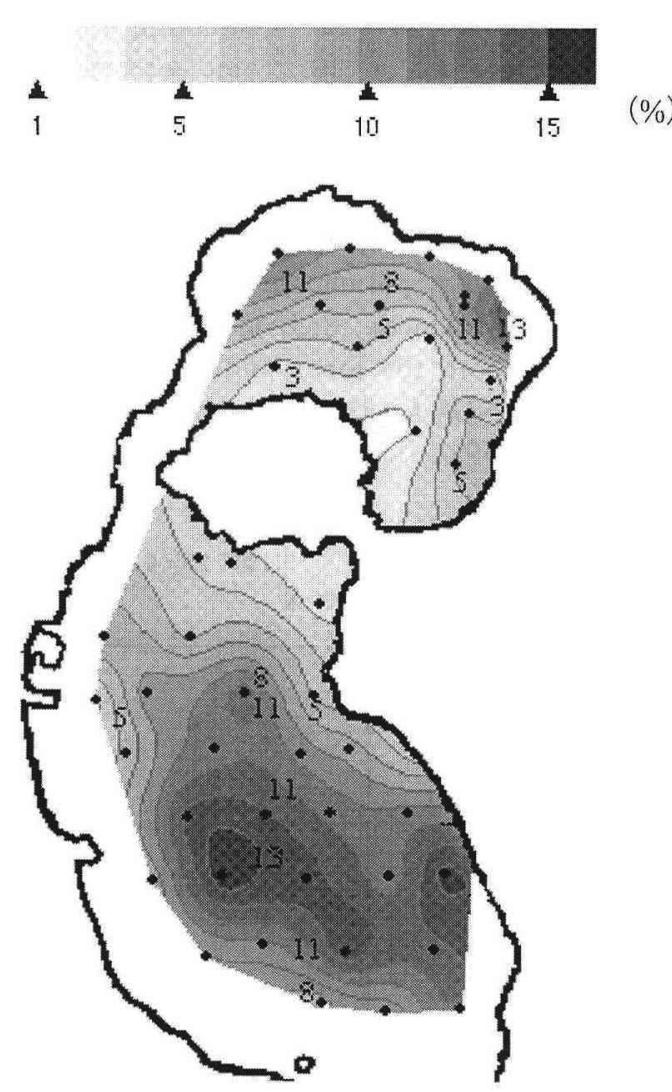

Fig. 4 a Ignition loss (IL ; \%) of sediment samples at $0-1$ $\mathrm{cm}$ layer collected in July 2001.

inner and central areas. In the inner area, IL of the sediments decreased with increasing sediment depths with highest values at the top $0-1 \mathrm{~cm}$ layer (Fig. $4 \mathrm{a}$ ). On the other hand, there was not so significant difference between the sediment layers in the central area.

Sedimentary total organic carbon (TOC) in the bay showed a broad range from $0.2 \%$ to $2.3 \%$ (Fig.5). The mean values of TOC at the top $0-1 \mathrm{~cm}$ sediment layer were similar between the inner and central areas $(1.08 \%$ and $1.17 \%$, respectively).

Total organic nitrogen (TON) in sediments of $\mathrm{Ka}$ goshima Bay (Fig. 6) ranged from $0.04 \%$ to $0.22 \%$ and showed similar trend with IL and TOC (Fig. 4b). The high TON values were observed in the stations at 1, 2, 10, and 11 of the inner area and in the stations at 29,33, and 41 of the central area. The lowest TON concentrations $(0.05 \%)$ were in the stations at 15 and 18 along the coast of Mt. Sakurajima. TON value at the top $0-1 \mathrm{~cm}$ was slightly higher in the inner area than that of in the central area. 


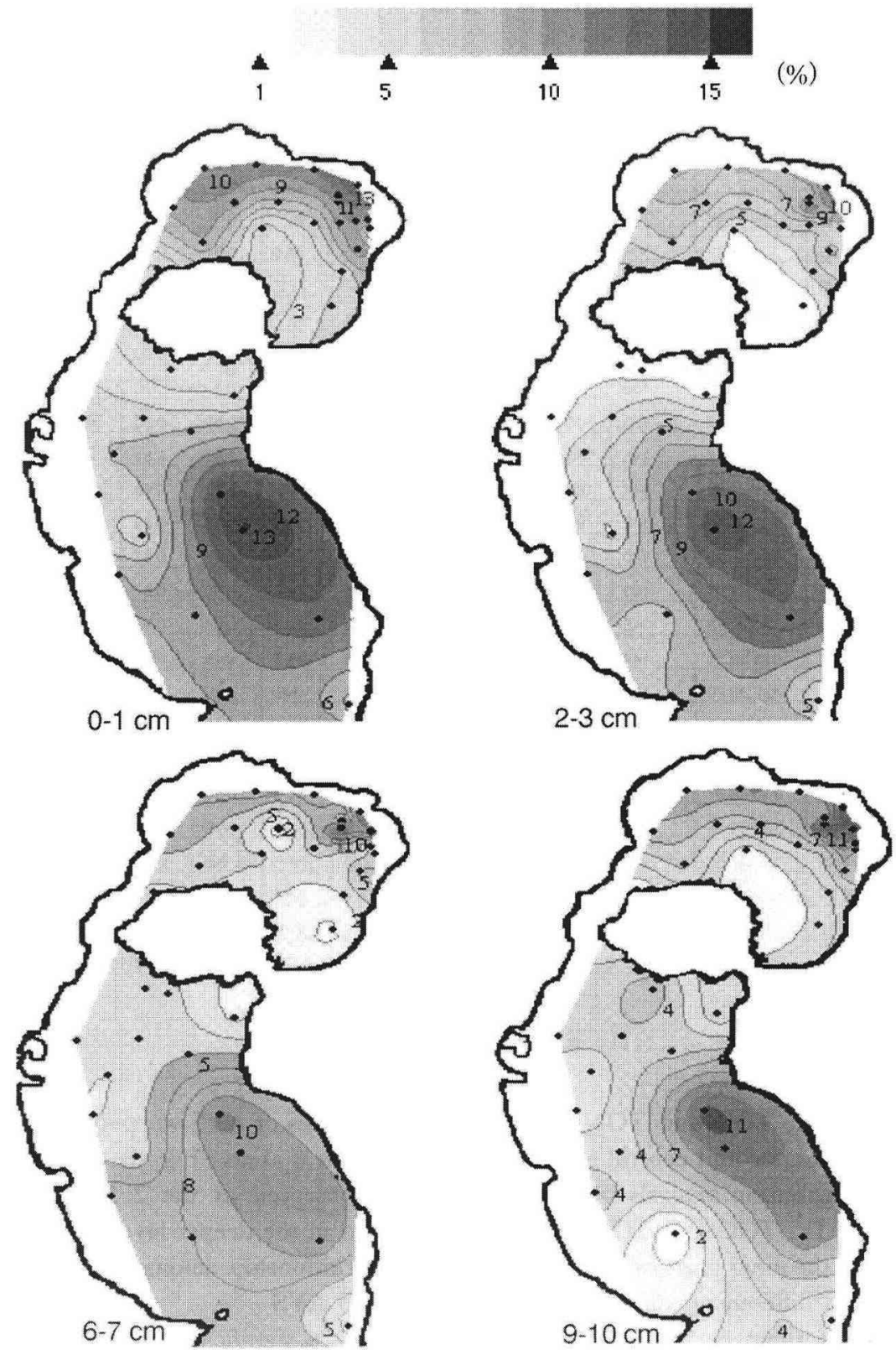

Fig. 4b Ignition loss (IL ; \%) of sediment samples at 0-1 cm, 2-3cm, 6-7 $\mathrm{cm}$ and 9-10 cm layers collected in August 2002. 
Table 1 Water content and porosity of sediments collected in July 2001 and August 2002 from different stations in the inner area of Kagoshima Bay.

\begin{tabular}{|c|c|c|c|c|c|c|c|c|c|c|c|c|c|}
\hline \multirow{3}{*}{$\begin{array}{l}\text { Sampling } \\
\text { station }\end{array}$} & \multirow[t]{3}{*}{ Latitude } & \multirow[t]{3}{*}{ Longitude } & \multirow{3}{*}{$\begin{array}{l}\text { Water } \\
\text { depth } \\
\text { (m) }\end{array}$} & \multicolumn{5}{|c|}{ Sedımentary water content (\%) } & \multicolumn{5}{|c|}{ Sedımentary Porosity } \\
\hline & & & & \multirow{2}{*}{$\begin{array}{l}\text { July } \\
\begin{array}{l}0-1 \\
\mathrm{~cm}\end{array} \\
\end{array}$} & \multicolumn{4}{|c|}{ August } & \multirow{2}{*}{$\begin{array}{l}\text { July } \\
0-1 \\
\mathrm{~cm}\end{array}$} & \multicolumn{4}{|c|}{ August } \\
\hline & & & & & $\begin{array}{l}0-1 \\
\mathrm{~cm}\end{array}$ & $\begin{array}{l}2-3 \\
\mathrm{~cm}\end{array}$ & $\begin{array}{l}6-7 \\
\mathrm{~cm}\end{array}$ & $\begin{array}{l}9-10 \\
\mathrm{~cm}\end{array}$ & & $\begin{array}{l}0-1 \\
\mathrm{~cm}\end{array}$ & $\begin{array}{l}2-3 \\
\mathrm{~cm}\end{array}$ & $\begin{array}{l}6-7 \\
\mathrm{~cm}\end{array}$ & $\begin{array}{l}9-10 \\
\mathrm{~cm}\end{array}$ \\
\hline 1 & $31^{0} 41.59$ & $130^{\circ} 44.59$ & 131 & 56.2 & 73.0 & 598 & 50.8 & 46.7 & 0.77 & 0.88 & 0.81 & 0.74 & 0.71 \\
\hline 2 & $31^{0} 40.43$ & $130^{\circ} 46.12$ & 199 & 806 & 74.0 & 68.4 & 46.5 & 58.6 & 0.91 & 0.88 & 0.85 & 0.70 & 0.80 \\
\hline 3 & $31^{\circ} 38.09$ & $130^{\circ} 47.10$ & 99 & 39.8 & 66.9 & 53.6 & 49.1 & 46.7 & 0.63 & 0.82 & 071 & 0.61 & 0.58 \\
\hline 4 & $31^{\circ} 36.66$ & $130^{\circ} 46.21$ & 141 & 82.1 & 63.7 & 56.0 & 41.4 & 36.7 & 0.92 & 0.82 & 0.78 & 0.65 & 0.60 \\
\hline 5 & $31^{\circ} 34.87$ & $130^{\circ} 45.53$ & 143 & 76.8 & 70.6 & 31.0 & 26.2 & 30.6 & 0.90 & 0.88 & 0.66 & 0.64 & 0.56 \\
\hline 6 & $31^{0} 36.30$ & $130^{\circ} 44.31$ & 138 & 40.0 & NS & NS & NS & NS & 0.63 & NS & NS & NS & NS \\
\hline 7 & $31^{0} 38.83$ & $130^{\circ} 44.57$ & 128 & 43.0 & 68.6 & 63.5 & 56.9 & 461 & 0.66 & 0.85 & 0.82 & 0.77 & 0.68 \\
\hline 8 & $31^{\circ} 39.84$ & $130^{\circ} 42.72$ & 145 & 65.9 & 66.9 & 54.5 & 46.1 & 46.0 & 0.83 & 0.84 & 0.78 & 0.71 & 0.71 \\
\hline 9 & $31^{0} 38.69$ & $130^{\circ} 41.88$ & 147 & 60.0 & 42.5 & 41.5 & NS & NS & 0.80 & 0.66 & 0.65 & NS & NS \\
\hline 10 & $31^{\circ} 42.11$ & $130^{\circ} 41.69$ & 143 & 69.0 & 72.8 & 61.5 & 59.4 & 55.6 & 0.85 & 0.89 & 0.83 & 0.80 & 0.77 \\
\hline 11 & $31^{\circ} 42.02$ & $130^{\circ} 39.36$ & 140 & 62.7 & 72.8 & 63.7 & 50.1 & 52.4 & 0.81 & 0.87 & 0.82 & 0.72 & 0.74 \\
\hline 12 & $31^{0} 39.84$ & $130^{\circ} 41.07$ & 100 & 64.6 & 71.6 & 61.6 & 68.1 & 44.5 & 0.83 & 0.87 & 081 & 0.85 & 0.68 \\
\hline 13 & $31^{0} 40.06$ & $130^{\circ} 37.73$ & 146 & 74.3 & 81.4 & 65.0 & 56.4 & 52.8 & 0.88 & 0.90 & 0.84 & 0.77 & 0.74 \\
\hline 14 & $31^{0} 38.31$ & $130^{\circ} 39.30$ & 142 & 57.4 & 81.5 & 64.9 & 50.2 & 48.4 & 0.78 & 0.92 & 0.84 & 0.74 & 071 \\
\hline 15 & $31^{0} 37.15$ & $130^{\circ} 36.79$ & 135 & 46.8 & 43.3 & 42.7 & 38.5 & NS & 0.69 & 0.66 & 0.66 & 0.62 & NS \\
\hline A1 & $31^{0} 39.84$ & $130^{\circ} 45.71$ & 205 & 91.3 & 73.9 & 65.7 & 61.0 & 61.6 & 0.96 & 0.88 & 0.85 & 0.83 & 0.83 \\
\hline $\mathrm{A} 2$ & $31^{0} 39.68$ & $130^{\circ} 46.96$ & 205 & NS & 75.5 & 63.5 & 55.6 & 70.7 & NS & 0.89 & 0.83 & 0.77 & 087 \\
\hline A3 & $31^{0} 39.31$ & $130^{\circ} 46.97$ & 205 & 89.3 & 71.5 & 56.8 & 53.2 & 68.6 & 0.96 & 0.87 & 0.78 & 0.75 & 0.85 \\
\hline $\mathrm{A} 4$ & $31^{0} 39.24$ & $130^{\circ} 46.13$ & 208 & NS & 75.3 & 60.0 & 49.6 & 56.6 & NS & 0.89 & 0.81 & 0.74 & 0.78 \\
\hline A5 & $31^{0} 39.29$ & $130^{\circ} 47.03$ & 210 & NS & 74.5 & 58.7 & 50.9 & 74.2 & NS & 0.89 & 0.79 & 0.74 & 0.88 \\
\hline $\mathrm{A} 6$ & $31^{0} 41.59$ & $130^{\circ} 4459$ & 205 & 90.6 & 61.6 & 53.8 & 53.4 & 52.2 & 0.96 & 0.80 & 0.75 & 0.75 & 0.74 \\
\hline A7 & $31^{\circ} 40.12$ & $130^{\circ} 47.37$ & 203 & 90.8 & 73.4 & 65.1 & 60.0 & 59.4 & 0.96 & 0.88 & 0.83 & 0.80 & 0.79 \\
\hline A8 & $31^{\circ} 41.12$ & $130^{\circ} 47.05$ & 162 & 84.0 & 87.8 & 81.4 & 64.1 & 59.5 & 0.93 & 0.95 & 0.92 & 0.82 & 0.80 \\
\hline
\end{tabular}

(NS-no samples collected)

Vertical distributions of IL, TOC and TON showed different trends between the inner and central areas. In the inner area, vertical distribution analysis showed decreasing concentrations of IL, TOC and TON with increasing sediment depths in the inner parts of the bay. On the other hand, no marked differences among sediment depths in concentrations of these parameters were observed in the central area.

\section{Acid volatile sulfide (AVS)}

In the $0-1 \mathrm{~cm}$ sediment layer, AVS concentrations ranged from 0.01 to $1.6 \mathrm{mg} /$ dry g in July 2001 and from 0.01 to $2.5 \mathrm{mg} / \mathrm{dry} g$ in August 2002 (Figs. $7 \mathrm{a}$ and $7 \mathrm{~b}$ ). The highest AVS values were observed in the stations of group A (from A1 to A8) and station 5 in the inner area. Comparably higher AVS values were found only in station 35 in July, 2001 and station 41 in August, 2002 in the central area.

Although mean values of AVS in the inner area were higher than those in the central area, the vertical distribu- tion profiles of AVS were similar between both the inner and central areas (Fig. 8). Highest AVS concentrations were observed at the $2-3 \mathrm{~cm}$ layer and gradually decreased in the deeper layers.

\section{Relationship among water content, IL, TOC, TON and AVS}

There is significant correlation between the water content with IL, TOC and TON. IL is also correlated well with TOC and TON. TOC and TON also showed significant correlation with each other. There were positive but weak correlation between AVS and sedimentary organic matter (Table 3).

\section{Discussion}

\section{Sedimentary organic matter}

The high TOC and TON values were observed in the stations at A1, A2, A3, A4, A6, A7, A8, 1, 2, 10, 11 of the inner area and in the deep parts, especially in the stations 
Table 2 Water content and porosity of sediments collected in July 2001 and August 2002 from different stations in the central area of Kagoshima Bay.

\begin{tabular}{|c|c|c|c|c|c|c|c|c|c|c|c|c|c|}
\hline \multirow{3}{*}{$\begin{array}{l}\text { Samplıng } \\
\text { station }\end{array}$} & \multirow[t]{3}{*}{ Latitude } & \multirow[t]{3}{*}{ Longitude } & \multirow{3}{*}{$\begin{array}{l}\text { Water } \\
\text { depth } \\
(\mathrm{m})\end{array}$} & \multicolumn{5}{|c|}{ Sedımentary water content (\%) } & \multicolumn{5}{|c|}{ Sedimentary porosity } \\
\hline & & & & \multirow{2}{*}{$\begin{array}{l}\text { July } \\
\begin{array}{l}0-1 \\
\mathrm{~cm}\end{array}\end{array}$} & \multicolumn{4}{|c|}{ August } & \multirow{2}{*}{$\begin{array}{l}\text { July } \\
0-1 \\
\mathrm{~cm}\end{array}$} & \multicolumn{4}{|c|}{ August } \\
\hline & & & & & $\begin{array}{l}0-1 \\
\mathrm{~cm}\end{array}$ & $\begin{array}{l}2-3 \\
\mathrm{~cm}\end{array}$ & $\begin{array}{l}6-7 \\
\mathrm{~cm}\end{array}$ & $\begin{array}{l}9-10 \\
\mathrm{~cm}\end{array}$ & & $\begin{array}{l}0-1 \\
\mathrm{~cm}\end{array}$ & $\begin{array}{l}2-3 \\
\mathrm{~cm}\end{array}$ & $\begin{array}{l}6-7 \\
\mathrm{~cm}\end{array}$ & $\begin{array}{l}9-10 \\
\mathrm{~cm}\end{array}$ \\
\hline 16 & $31^{0} 34.00$ & $130^{\circ} 35.62$ & 37 & NS & NS & NS & NS & NS & NS & NS & NS & NS & NS \\
\hline 17 & $31^{0} 31.32$ & $130^{\circ} 34.94$ & 64 & NS & NS & NS & NS & NS & NS & NS & NS & NS & NS \\
\hline 18 & $31^{0} 31.80$ & $130^{\circ} 3762$ & 175 & 52.9 & 419 & 35.3 & 44.4 & 48.2 & 0.74 & 0.65 & 059 & 0.67 & 071 \\
\hline 19 & $31^{0} 30.02$ & $130^{\circ} 33.37$ & 41 & 55.5 & 525 & 34.8 & 36.7 & 32.5 & 0.76 & 0.74 & 0.58 & 0.60 & 0.39 \\
\hline 20 & $31^{0} 30.03$ & $130^{\circ} 35.95$ & 124 & 57.0 & 65.0 & 42.7 & 45.0 & 40.0 & 0.77 & 0.84 & 0.68 & 0.68 & 0.66 \\
\hline 22 & $31^{0} 31.07$ & $130^{\circ} 41.07$ & 130 & 58.6 & 54.0 & 39.1 & 33.6 & 214 & 0.79 & 0.77 & 0.67 & 0.61 & 0.49 \\
\hline 23 & $31^{0} 27.71$ & $130^{\circ} 40.59$ & 93 & 46.4 & NS & NS & NS & NS & 0.69 & NS & NS & NS & NS \\
\hline 24 & $31^{0} 27.79$ & $130^{\circ} 40.59$ & 163 & 81.7 & NS & NS & NS & NS & 0.92 & NS & NS & NS & NS \\
\hline 25 & $31^{0} 27.79$ & $130^{\circ} 35.08$ & 94 & 59.8 & 52.4 & 42.4 & 38.7 & 33.1 & 0.79 & 0.78 & 0.69 & 0.63 & 0.56 \\
\hline 26 & $31^{0} 27.62$ & $130^{\circ} 32.79$ & 31 & 35.7 & NS & NS & NS & NS & 0.59 & NS & NS & NS & NS \\
\hline 27 & $31^{0} 25.80$ & $130^{\circ} 34.23$ & 82 & 48.0 & 54.6 & 46.9 & 36.9 & 33.4 & 0.70 & 0.76 & 0.71 & 0.60 & 0.57 \\
\hline 28 & $31^{0} 25.92$ & $130^{\circ} 36.87$ & 168 & 62.3 & NS & NS & NS & NS & 081 & NS & NS & NS & NS \\
\hline 29 & $31^{0} 25.80$ & $130^{\circ} 39.88$ & 224 & 68.0 & 73.8 & 70.2 & 66.2 & 64.8 & 0.85 & 0.89 & 0.87 & 0.80 & 0.79 \\
\hline 30 & $31^{0} 25.91$ & $130^{\circ} 42.09$ & 170 & 66.9 & NS & NS & NS & NS & 0.84 & NS & NS & NS & NS \\
\hline 31 & $31^{0} 25.91$ & $130^{\circ} 44.43$ & 54 & 47.0 & NS & NS & NS & NS & 0.70 & NS & NS & NS & NS \\
\hline 32 & $31^{0} 23.91$ & $130^{\circ} 43.72$ & 125 & 80.0 & NS & NS & NS & NS & 0.91 & NS & NS & NS & NS \\
\hline 33 & $31^{0} 23.91$ & $130^{\circ} 41.30$ & 213 & 74.0 & 81.5 & 81.0 & 65.7 & 63.6 & 0.88 & 0.92 & 0.92 & 0.84 & 0.83 \\
\hline 34 & $31^{0} 23.85$ & $130^{\circ} 38.73$ & 230 & 77.6 & NS & NS & NS & NS & 0.90 & NS & NS & NS & NS \\
\hline 35 & $31^{0} 23.80$ & $130^{\circ} 35.91$ & 193 & 86.0 & 36.3 & 32.6 & 32.5 & 33.9 & 0.94 & 0.61 & 0.55 & 0.55 & 0.57 \\
\hline 36 & $31^{0} 21.82$ & $130^{\circ} 35.19$ & 94 & 64.1 & 64.3 & 59.0 & 53.1 & 45.2 & 0.82 & 0.83 & 0.79 & 0.76 & 0.69 \\
\hline 37 & $31^{0} 21.92$ & $130^{\circ} 37.46$ & 218 & 82.4 & NS & NS & NS & NS & 0.92 & NS & NS & NS & NS \\
\hline 38 & $31^{0} 21.88$ & $130^{\circ} 40.41$ & 213 & 81.3 & NS & NS & NS & NS & 0.92 & NS & NS & NS & NS \\
\hline 39 & $31^{0} 21.92$ & $130^{\circ} 42.92$ & 195 & 74.8 & NS & NS & NS & NS & 0.88 & NS & NS & NS & NS \\
\hline 40 & $31^{0} 21.97$ & $130^{\circ} 45.33$ & 89 & 61.2 & NS & NS & NS & NS & 0.80 & NS & NS & NS & NS \\
\hline 41 & $31^{0} 1972$ & $130^{\circ} 44.72$ & 127 & 72.0 & 69.5 & 70.0 & 64.3 & 62.5 & 0.87 & 0.87 & 0.86 & 0.84 & 0.83 \\
\hline 42. & $31^{0} 19.68$ & $130^{\circ} 41.66$ & 177 & 724 & NS & NS & NS & NS & 0.87 & NS & NS & NS & NS \\
\hline 43 & $31^{0} 17.93$ & $130^{\circ} 41.00$ & 112 & 48.2 & NS & NS & NS & NS & 0.71 & NS & NS & NS & NS \\
\hline 44 & $31^{0} 19.83$ & $130^{\circ} 39.09$ & 192 & 52.5 & 60.8 & 52.8 & 55.0 & ND & 0.74 & 0.80 & 0.76 & 077 & ND \\
\hline 45 & $31^{0} 19.55$ & $130^{\circ} 36.71$ & 130 & 53.3 & NS & NS & NS & NS & 0.75 & NS & NS & NS & NS \\
\hline 46 & $31^{0} 17.78$ & $130^{\circ} 43.30$ & 135 & 55.7 & NS & NS & NS & NS & 0.76 & NS & NS & NS & NS \\
\hline 47 & $31^{0} 17.82$ & $130^{\circ} 46.07$ & 110 & 75.9 & NS & NS & NS & NS & 0.89 & NS & NS & NS & NS \\
\hline
\end{tabular}

(NS-no samples collected)

29, 33 and 41 of the central area. The faster sediment supply (The Science and Technology Agency, 1976; Takahashi, 1981) resulting in a high IL, TOC and TON in the inner area would be attributed to aquaculture effluents and discharge from the rivers. The high sedimentation rate in this area can reduce the contact time between organic matter and dissolved oxygen in the water column, and therefore can contribute to higher concentrations of carbon and nutrients in sediments (Enriquez et al, 1993). In the central area, the bottom topography and the currents northward and southward along the Osumi
Peninsula and Satsuma Peninsula, respectively, as well as the counterclockwise current in the northern margin of the central area, may have affected strongly the accumulation of IL in deepest stations 29, 33 and 41. High sedimentation rates in these stations were also reported by Oki (1989).

The data indicated that the vertical distributions of IL, TOC and TON in the inner area decreasing with the increasing sediment depth, while in the deep part of the central area this trend was not observed. Hedges and Keil (1995) reported that organic matter has a high 


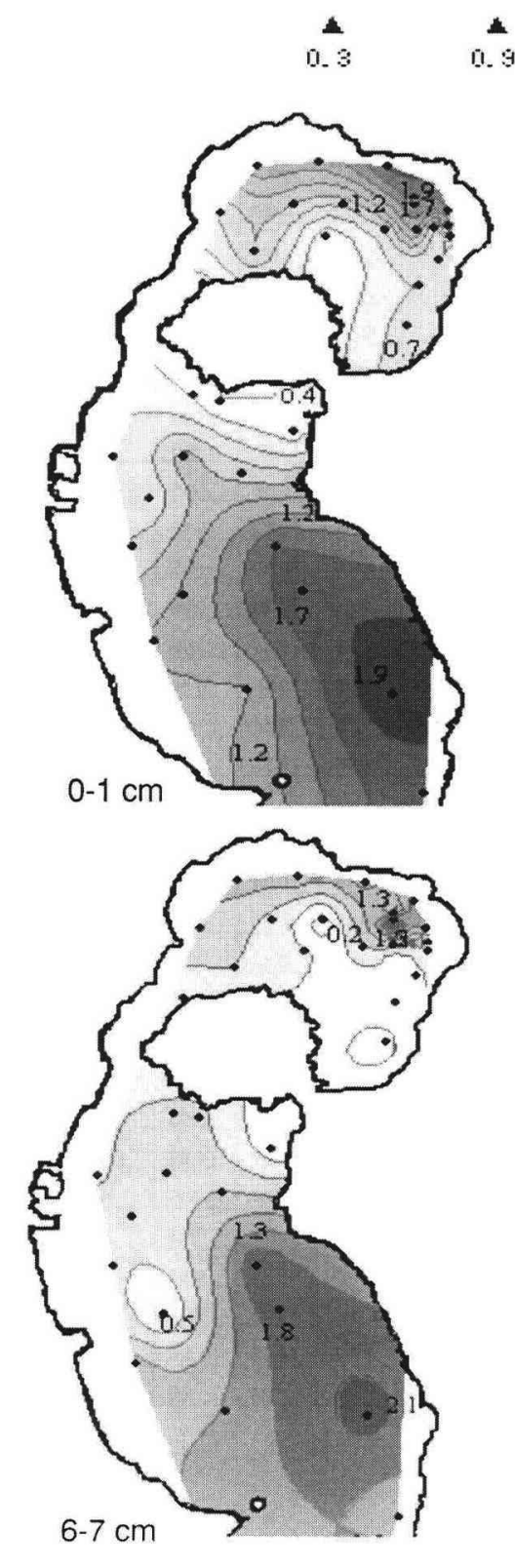

1.
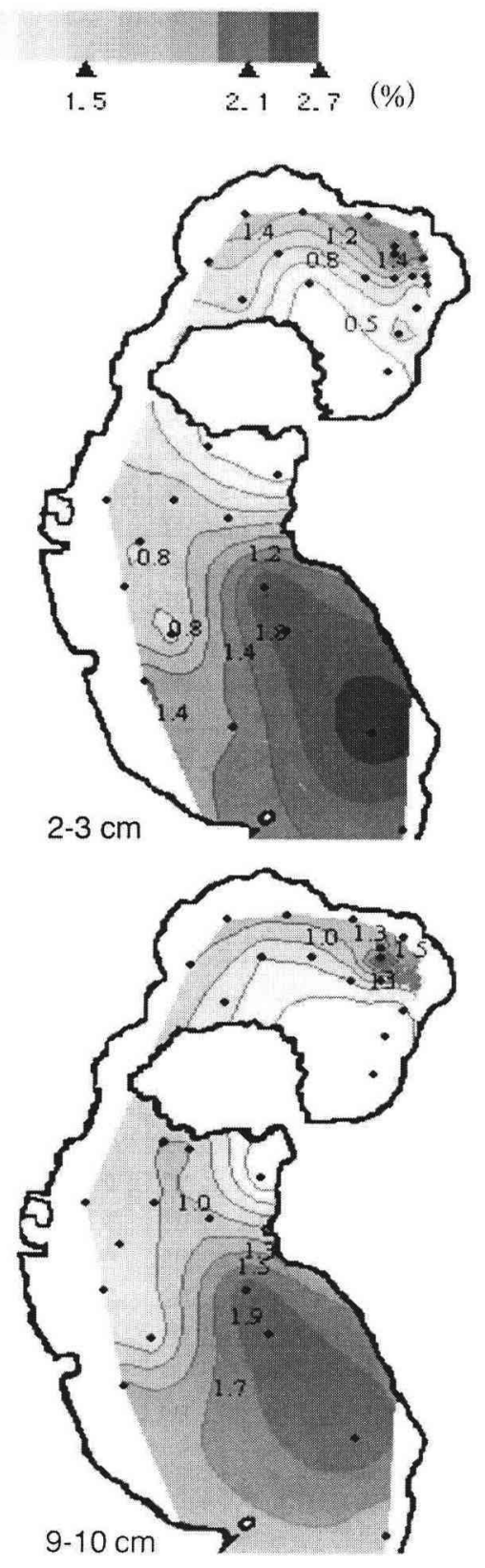

Fig. 5 Total organic carbon (TOC ; \%) of sediment samples at of $0-1 \mathrm{~cm}$, $2-3 \mathrm{~cm}, 6-7 \mathrm{~cm}$ and $9-10 \mathrm{~cm}$ layers collected in August 2002. 
1.
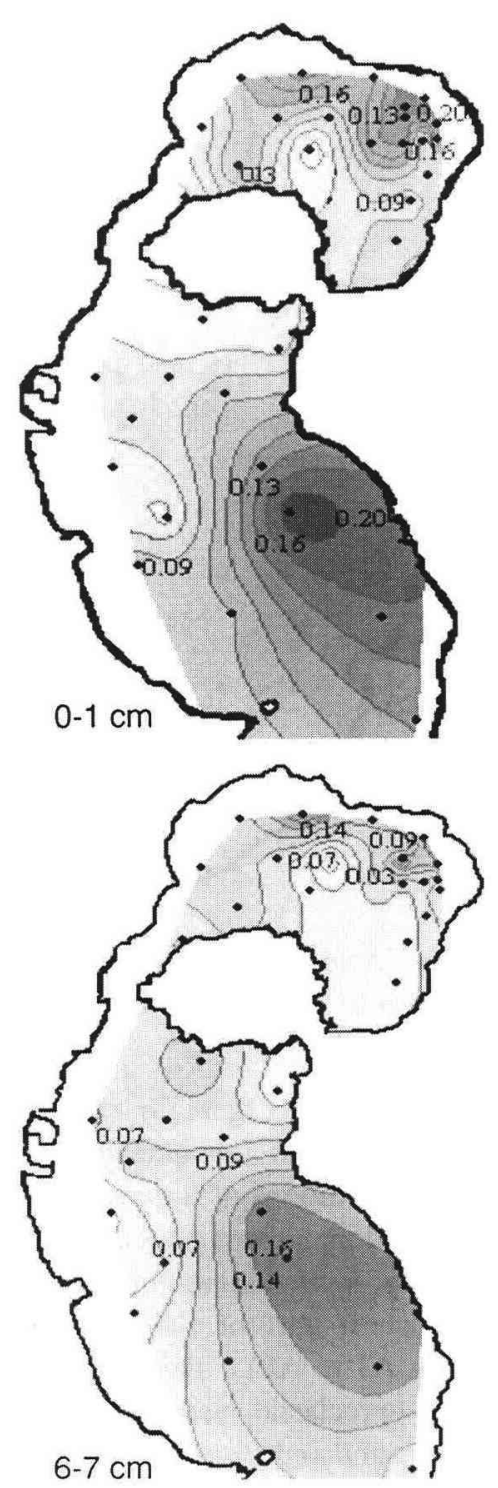

1. 15

$0.30(\%)$
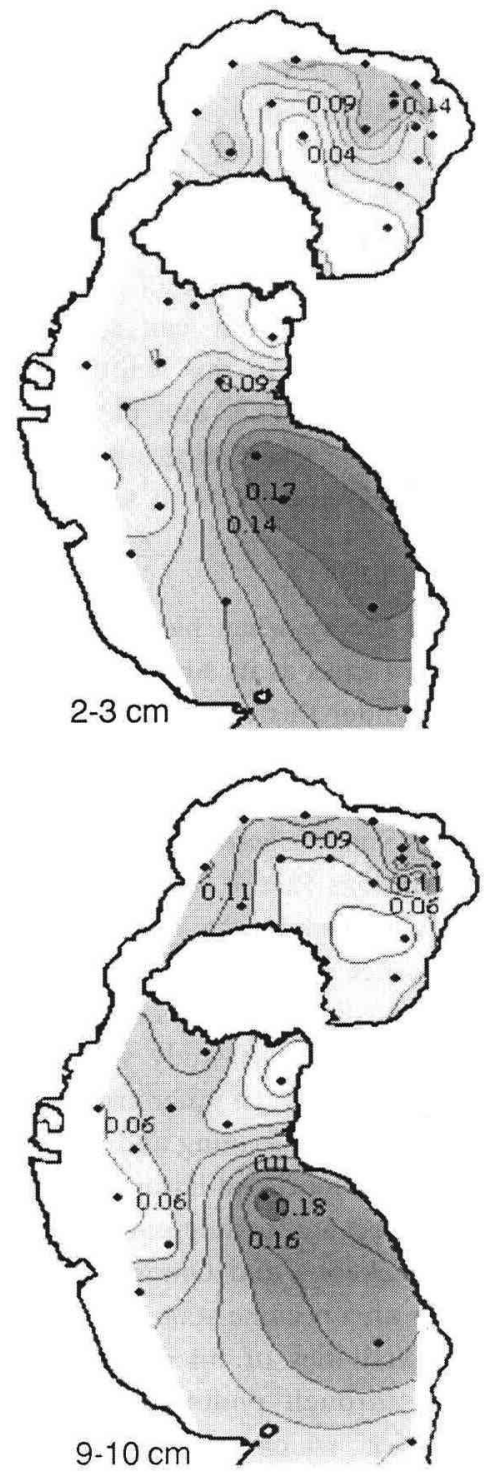

Fig. 6 Total organic nitrogen (TON ; \%) of sediment samples at of $0-1$ $\mathrm{cm}, 2-3 \mathrm{~cm}, 6-7 \mathrm{~cm}$ and $9-10 \mathrm{~cm}$ layers collected in August 2002. 
affinity with fine-grained clastic particles. The adsorption process helps to preserve the organic matter (De la Lanza-Espino and Soto, 1999) and give rise to a generally positive correlation between TOC and mud\%. In the deep part of the central area, the higher sedimentation rates (Oki, 1989) were reported as well as the high mud content and smaller grain size (Hidaka, unpublished data), which may result in IL, TOC and TON accumulation in deeper sediment layers.

CSIRO Huon Estuary Study Team (2000) reported that the ignition loss method for determine of sediment TOC was not recommended because it can seriously overestimate TOC concentrations. In this study, however, the strong correlation between TOC and TON with IL in sediments were found. The result suggests that IL can be a good proxy for TOC and TON in sediments under certain conditions.

\section{Acid volatile sulfide}

Anoxic condition usually occurs when biological and chemical demands for oxygen exceeds its supply through the atmospheric diffusion. Under this condition, decomposition of organic matter leads to anaerobic condition causing liberation of sulfide into bottom water.

The concentrations of AVS investigated at the $0-1 \mathrm{~cm}$ sediment depth at many stations in the inner area are higher than those values observed in the central area. These results suggest the absence of dissolved oxygen and higher organic loading in the sediments of this area. The dissolved oxygen data observed in this study show the hypoxia condition at many stations in the inner area (Fig. $3)$. The correlation between organic loading and benthic oxygen uptake was reported by Omori and Hirano (1994) and the correlation between organic loading and AVS in sediment was reported by Takeoka and Omori (1996). When the water in the inner area became stagnant, respiration and decomposition activities of microorganisms exceed oxygen production through photosynthesis, as well as by atmospheric diffusion, which resulted in depletion of oxygen. The depletion of oxygen in areas of high organic matter accumulation changes benthic metabolic processes from aerobic to anaerobic decomposition of organic matter (Meyer-Reil and Koster, 2000), causing liberation of hydrogen sulfide in sediment, which resulted in increasing the AVS concentrations.

The same hypoxia condition may be present in the deep part of the central area as evidenced by high AVS and TOC at the station 41 (August 2002). Otherwise, hypoxia condition may not had happened at the surface top sediment layer at most stations in the central area different from those in the inner area. This suggests that

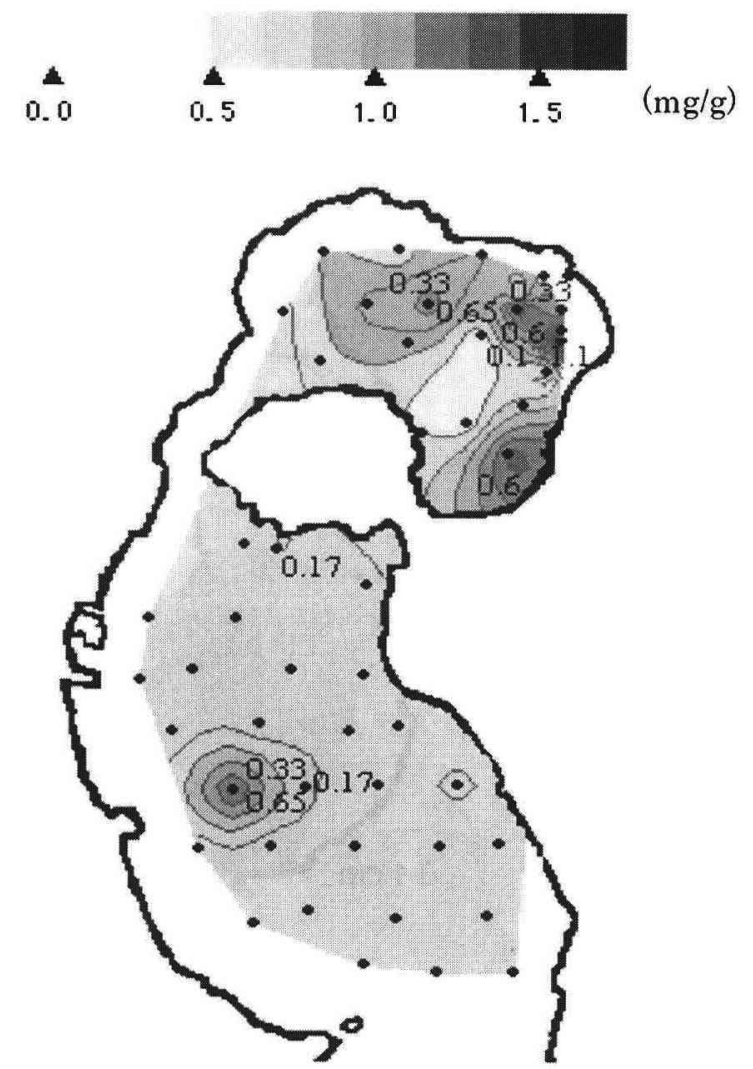

Fig. 7a Acid volatile sulfide (AVS; mg/g) of sediment samples at 0-1 cm layer collected in July 2001.

accumulation of organic matter in the surface sediments of deep basin in the inner area would be a result of coupled conditions of hypoxia and the release of AVS.

In addition, highest AVS concentrations, exceptional in this study, were observed in a 200-meter deep basin in the northeastern part of the inner area (in the group of stations A1 to A8). This could be attributed to the fall out of pyroclastic materials from Mt. Sakurajima and underground emissions through the volcanic vents at the bottom of the bay (Kamada et al., 1977 ; Kagoshima Prefecture Government, 1978).

\section{Conclusions}

The results from this study give us a clear picture of the horizontal and vertical characterization of sediments in Kagoshima Bay in terms of organic matter and acid volatile sulfide distributions. High values of sedimentary organic matter (include IL, TOC and TON) and AVS are observed at many stations in the inner area and in the deep basin in the central area. Vertical distribution 

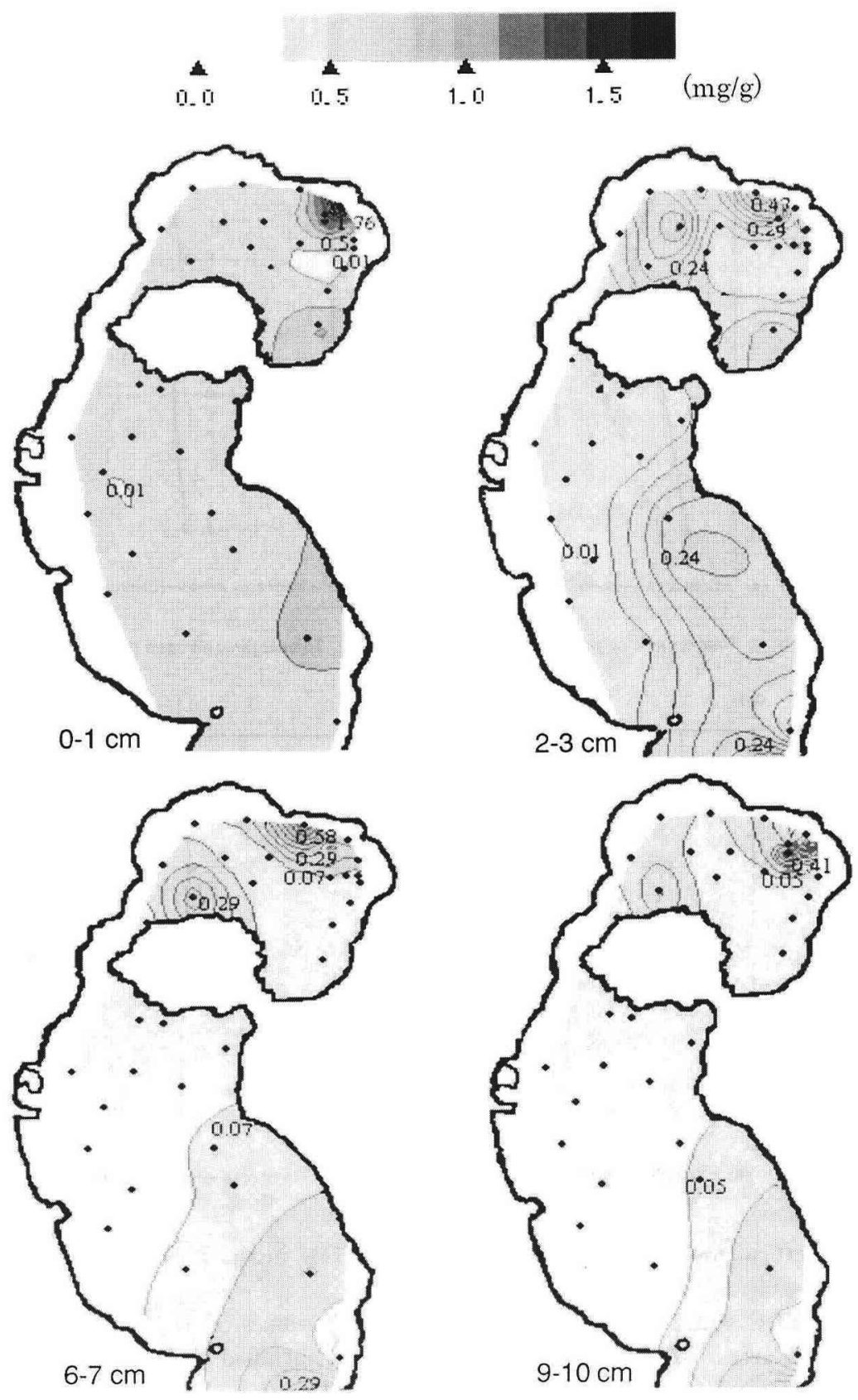

Fig. 7 b Acid volatile sulfide (AVS ; $\mathrm{mg} / \mathrm{g}$ ) of sediment samples at of $0-1$ $\mathrm{cm}, 2-3 \mathrm{~cm}, 6-7 \mathrm{~cm}$ and $9-10 \mathrm{~cm}$ layers collected in August 2002. 

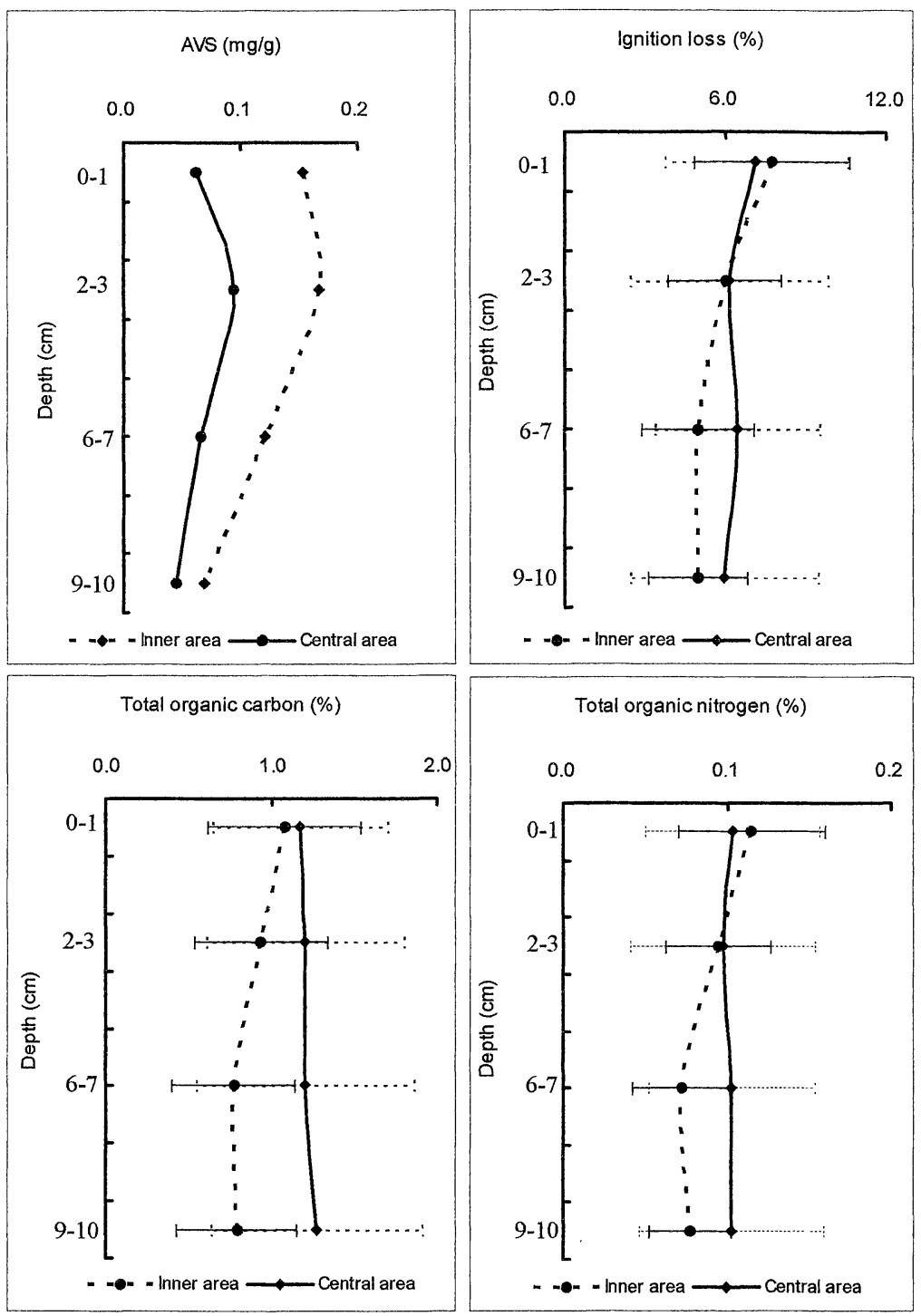

Fig. 8 Vertical distribution of AVS, IL, TOC, TON in the inner and central areas. Data were collected in August 2002.

AVS, IL, TOC and TON in this figure were average values of all stations in the inner and central areas. The data in the inner area not included the group of station $\mathrm{A}$. Dotted line : the inner area, straight line : the central area.

Table 3 Correlations (Pearson, $\mathrm{P}<0.01$ ) among water content, IL, TOC, TON and AVS.

\begin{tabular}{|c|c|c|c|}
\hline & $\mathrm{IL}$ & TOC & TON \\
\hline Water content & 0.80 & 0.55 & 0.73 \\
\hline AVS & 0.43 & 0.37 & 0.41 \\
\hline TOC & 0.84 & & 0.84 \\
\hline TON & 0.82 & 0.84 & \\
\hline
\end{tabular}


analysis showed decreasing concentrations of IL, TOC and TON with increasing sediment depths in the inner parts of the bay and no marked differences in concentrations of these parameters in the central area. The strong correlation among the levels of sedimentary TOC, TON and IL suggests that IL can be a good proxy for TOC and TON in marine sediments, at least in this particular case. The accumulation of organic matter in the surface sediment of deep basin in the inner area would be a result of coupled conditions of hypoxia and the release of AVS. On the basis of these results, it is possible to conclude that sedimentary organic matter (IL, TOC and TON) and AVS can be considered as useful indicators in assessing the environmental quality of Kagoshima Bay.

\section{References}

CSIRO Huon Estuary Study Team, 2000 : Huon Estuary Study: Environmental research for intergrated catchment management and aquaculture. Project No. 96/284, Final report to the Fisheries Research and Development Corporation, $285 \mathrm{p}$.

Danovaro, R., Marrale, D., Della Croce, N., Parodi, P. and Fabiano, M., 1999 a : Biochemical composition of sedimentary organic matter and bacterial distribution in the Aegean Sea : trophic state and pelagic-benthic coupling. Journal of Sea Research, 42, 117-129.

De la Lanza-Espino, G. and Soto, L. A., 1999 : Sedimentary geochemistry of hydrothermal vents in Guaymas Basin, Gulf of California, Mexico. Applied Geochemistry, 14, 499-510.

Enriquez, S., Duarte, C.M. and Sand-Jensen, K., 1993 : Patterns in decomposition rates among photosynthetic organisms : the importance of detritus $\mathrm{C}: \mathrm{N}: \mathrm{P}$ content. Oecologia, 94, 457-471.

Fabiano, M. and Danovaro, R., 1994 : Composition of organic matter in sediments facing a river estuary (Tyrrhenia Sea) : relationships with bacteria and microphytobenthic biomass). Hydrobiologia, 227, 71-84.

Fabiano, M., Danovaro, R. and Fraschetti, S., 1995 : Temporal trend analysis of the elemental composition of the sediment organic matter in subtidal sandy sediments of the Ligurian Sea (NW Mediterranean) : a three years study. Continental Shelf Research, 15, 1453-1469.

Grasshoff, K., Kremling, K. and Ehrharardt, M., 1999 : Methods of seawater analysis. WILEY-VCH Verlag, Weinheim, $600 \mathrm{p}$.

Hedges, J. I. and Keil, R. G., 1995 : Sedimentary organic matter preservation : an assessment and speculative hypothesis. Marine Chemistry, 49, 81-115.

Heijs, S. K., Jonkers, H. M., van Germerden, H., Schaub, B. E. M. and Stal, L. J., 1999 : The buffering capacity towards free sulfide in sediments of a coastal lagoon (basin d'Arcachon, France) - the relative importance of chemical and biological processes. Estuarine, Coastal and Shelf Science, 49, 21-35.

Kagoshima Prefecture Government, 1978 : Report on the environment study in relation to mercury in Kagoshima Bay. 38 p. (in Japanese)

Kamada, M., Sakamoto, H., Yonehara, N. and Onishi, T., 1977 : Unusual property of water in the Bay-head area of Kagoshima Bay. Submarine volcanic activities and unusual environmental conditions in the Bay-head area North of Mt. Sakurajima, 64-80. (in Japanese)

Kazuyuki, Y., 1991 : On the controlling effect of the planned management of the environment in the Kagoshima bay on the Pollutant load. Marine Pollution Bulletin, 23, 525531.

Kimata, M., Kawai, A. and Ishida, Y., 1960 a : The method of sampling of marine bottom muds. Bull. Japan. Soc. Sci. Fish., 26, 1227-1230. (in Japanese).

Maeda, H., 2001 : Water quality of Kagoshima Bay. Bull. Mar. Resour. Environ. Kagoshima Univ., 9, 1-7. (in Japanese)

Meyer-Reil, L.A. and Koster, M., 2000 : Eutrophication of marine water : effects on benthic microbial communities. Marine Pollution Bulletin, 41, 255-263.

Nixon, S. W., 1995 : Coastal marine eutrophication : a defininition, social causes, and future concerns. Ophelia, 41, 199-219.

Oki, K., 1989 : Ecological analysis of benthonic foraminifera in Kagoshima bay. South Pacific Study, 10, 179 p.

Omori, K. and Hirano, T., 1994 : The limitation to organic loading on a bottom of a coastal ecosystem. Marine Pollution Bulletin, 28, 73-80.

Postgate, J.R., 1984 : The sulphate-reducing bacteria. Cambridge Univ. Press, Cambridge, $208 \mathrm{p}$.

Takahashi, T., 1981 : Seasonal differences of the circurlation processes in a coastal basin nearly closed by land. Ocean Management, 6, 189-200.

Takeoka, H. and Omori, K., 1996 : Methods of determining the limit of suitable fish culture based on the oxygen consumption rate by sediment. Bull. Jpn. Soc. Fish. Oceanogr., 60, 45-53. (in Japanese with English abstract)

The Science and Technology Agency, 1976 : Report on the coastal erosion at Shinjima Island, Kagoshima Prefecture. $139 \mathrm{p}$.

Truper, H. G. and Schelegel, H. G., 1964 : Sulphur metabolism in Thiorhodaceae. I. Quantitative metabolism in growing cultures of Chromatium okenii. Antonie van Leeuwenhoek, 30, 225-238.

Vollenweider, R.A., Giovanadi, F., Montanari, G. and Rinaldi, A., 1988 : Characterization of the trophic conditions of marine coastal water with special reference to the NW Adriatic Sea : proposal for atrophic scale. Turbidity and generalized water quality index. Environmetrics, 9, 329-357. 


\section{鹿児島湾における環境指標としての堆積有機物および硫化物}

Nguyen Dung Thi Phuong · 前田広人 ・ 田岡洋介 ・ 日高正康 · 吉川 毅 - 坂田泰造, 2005, 堆積学研究, No. 62, 17-30

Nguyen Dung Thi Phuong, Maeda, H., Taoka, Y., Hidaka, M., Yoshikawa, T. and Sakata, T. : Sedimentary organic matter and acid volatile sulfide as environmental quality indicators of Kagoshima Bay Jour. Sed. Soc. Japan, No. 62, 17-30

富栄養化に伴う底質の動態を明らかにするために, 種々の指標を比較して鹿児島湾における底質 の特徵づけをおこなった，本研究では, 富栄養化の程度を知る指標として堆積物中の有機物之酸可 溶性硫化物 (AVS) の分析を行った. 2001 年 7 月と 2002 年 8 月に堆積物試料の採取を行った. 底泥 の有機物とAVS 濃度は均一ではなく高濃度域がみられ，その傾向は 2 回のサンプリングについて ほぼ同様であった。強熱減量（IL）は 1.1-13.4\%で, 有機炭素（TOC）および有機窒素（TON）は それぞれ，0.2-2.3\% および 0.04-0.22\%の範囲で変動した.AVS 濃度は 0.01-2.5 mg $/ \mathrm{g}$ (乾泥）の範 囲であり, 湾奥の最深部で高濃度であった。 TOC および TON の濃度が IL 濃度と平行して増加し たことから TOC と TON が IL と相関していると考えられた，湾奥部では，底泥における IL, TOC, TON 濃度は泥深とと屯に減少した。一方，湾央部の鉛直分布については，これらの指標の大 きな変動は見られなかった．以上の結果は鹿児島湾における底泥の水平および鉛直的な分布の特徵 を明瞭に示している．さらに有機物とAVS 濃度が鹿児島湾の環境状態を知る指標として使用でき ることが示された。 